\title{
Can online transportation support low carbon?
}

\author{
Anita Ratnasari Rakhmatulloh ${ }^{1, *}$, Talitha Zuleika Islamey ${ }^{2}$, and Diah Intan Kusumo Dewi ${ }^{1}$ \\ ${ }^{1}$ Departement of Urban and Regional Planning, Faculty of Engineering, Diponegoro University, Semarang-Indonesia \\ ${ }^{2}$ Undergraduate Program of Urban and Regional Planning Department, Faculty of Engineering, Diponegoro University, Semarang- \\ Indonesia
}

\begin{abstract}
The existence of online transportation is one of the alternative priority modes in transportation. Online transportation has the concept of car sharing, mainly by the uses of vehicles together. The function of car-sharing is expected to reduce the number of vehicles use. Through the concept of car sharing, it can help to realize the concept of a low-carbon city. In previous studies, people prefer to choose private cars than public transportation, because of their easiness in mobility and short travel time. Online Transportation is also efficient same as private vehicles, regarding mobility and travel time. Thus, Online Transportation is expected to reduce the usage of private vehicles and create more environmentally friendly. Based on this phenomenon, researchers want to explore the purpose of the preference for online transportation. The result finds out that the variables could influence the choices of online transportation. This research was conducted using the utility of transportation mode selection model.
\end{abstract}

Keyword: Online transportation; Mode Utility; Low Carbon.

\section{Introduction}

Improved quality of life and economic prosperity in urban areas can be achieved with accessibility [1] and good mobility [2]. High mobility will cause congestion if not matched by good urban transport. The Municipal Government has attempted to provide mass public transportation as a solution to reduce congestion. Mass public transport is currently widely used by office employees, students, collager and workers [3]. Mass public transport needs increase during peak hours, judging by the hustle and bustle of workers and students waiting at bus stops around residential, school, work or office locations. Public transportation is needed by travel agents, especially those who do not have a private vehicle and not old enough to have a driver's license. But the existence of mass public transportation has not been able to reach the whole region. It is indicated by there are still areas that are not bypassed by public transit routes [4]. People feel less comfortable and choose to use private vehicles. Conditions like this do not reduce congestion, because the number of private vehicles is increasing.

Nowadays technological developments have facilitated the community to travel with the provision of online transport applications. The application provides transportation services to the community more easily and quickly. It is done in the form of ease in the process of booking transportation services. The ease helps the users to make time more useful more efficiently. Thus, the value of money and time value spent is not in vain simply because of transportation problems [3].

Currently, the urgency of online transportation is to reduce the possibility of using mass public transportation. Based on the data from IDN TIMES, the number of people using online transportation in Indonesia is around 15 million peoples. The public transport user in Diponegoro University (Semarang) also has decreased, as reported at Solopos.com on August 25th, 2017; it is expected about $70 \%$ in revenue decrease, which is suspected due to the increase of online transportation usage. Furthermore, the driver's income also showed that the uses of mass public transport might decreased in Diponegoro University area.

Create urban transportation that supports the concept of a low-carbon city; it can be tested for the choice of transportation modes with its utility function. Calculating the utility cost value and time utility of the selection of modes which can then be estimated the probability of election of the mode of online transportation and public transportation. With these results can be seen the reason for the selection of modes made by the city of Semarang at this time. Then with a solution or improvement on public transportation done to divert the choice of people to prefer mass public transportation back. So that the number of vehicles operating on the road can be reduced and reduce the emissions of $\mathrm{CO} 2$ gas is wasted.

\footnotetext{
*Corresponding author: anita.ratnasari.r@gmail.com
} 


\section{Literature Review}

\subsection{Utility Of Modes Choice}

In the mode of transportation selection, the utility value of a mode becomes an influencing factor in the determination of choice. The approach with this utility value is in the uncertainty of the user choosing the mode to be used in the observations made [5].

Based on the selection of modes of transportation, utility values can be obtained based on travel time and travel costs paid by users. In the final selection will be selected an alternative that has the highest utility value among all alternatives. The possibility of choosing an alternative is the possible utility felt by the traveler. Then the formulation of total transportation utility value is as follows [6]:

Where:

$$
\mathbf{U}_{\mathbf{J}}=a+b_{1} x_{1}+\ldots . b_{n} x_{n}
$$

$\mathrm{Uj}$ : utility value of $\mathrm{j}$ choice

$a, b_{1}, \ldots b_{n}$ : the utility component that influences the alternative option (attribute coefficient)

$\mathrm{x}_{1}, \mathrm{x}_{2, \ldots} \mathrm{x}_{3} \quad$ : attribute value

\subsection{Online transportation}

Online transportation is classified as a category of rental transportation which in the order has been adjusted with technological advancements that continue to grow rapidly. The current system of online transportation usage can be said to be the development of the ridesharing system. The development of today's ride-sharing system is by combining digital elements and transport, thus creating an app for online ride-sharing systems known as online transport today.

Although online transport is a development of a ridesharing system, the current existence of online transport is not like the ride-sharing at the time it first appeared in the 1940s. Online transport is more like a chartered transport or paratransit which is transportation provided by a service company to be used by a tenant for the sole purpose of the individual. So the existence of online transportation is increasingly increasing the number of vehicles that operate.

\subsection{Low Carbon City}

The meaning of the Low Carbon City according to the World Wide Fund for Nature (WWF) is a city that refers to the level of resource consumption and low $\mathrm{CO} 2$ emissions levels in the fast-growing economic development [7]. The indicator of low-carbon cities can be seen through 7 indicators as follows economic, energy, water, life and social, environment and carbon, solid waste and urban mobility [8].

Transportation is one sector that uses fuel oil (BBM) is quite large. The use of fuel from fossil energy will result in greenhouse gas emissions (GHG), which is one of the causes of global warming. The high number of motor vehicles will undoubtedly increase the emissions of gas wasted into the air. The following actions can be taken in the transport sector to support low-carbon cities [9]:

a. The transition of passenger mode from the use of private vehicles to public transportation to improve energy use efficiency.

b. Use of low-emission vehicles for passenger transportation. Such as the use of electric vehicles and hydrogen fuel cells.

c. The transition of freight mode from highway transportation to more efficient modes of transportation such as trains.

d. Establish vehicle emissions standards and fuel specifications.

e. Restructuring the vehicle taxation system by including incentives based on vehicle emission levels.

\section{Research Methods}

\subsection{Data Collecting Methods}

The variables used in research on the utility of selection of this mode are:

1. characteristics of online transportation and mass public transportation in the form Trans Semarang

2. Selection of transportation modes for the movement of daily activities.

3. The cost/cost of the user's journey from each mode of transportation

4. User travel time by using different modes of transportation

\subsection{Total sample analysis}

The population studied is not known yet, but has the criteria of ever using the services of online transportation. Thus the formula used in determining the sample size is the Wibisono formula [10] and obtained a total sample of at least 97 samples.

\subsection{Analysis of choice utility of online transportation mode}

This study analyzes the selection of modes made by the user in traveling for his daily activities. The utility value seen is based on three main things in the selection of modes is distance, cost and time. For distance in this mode selection is considered the same. Therefore the value of utility studied is the value of travel costs and travel time of each mode. After obtaining utility value of mode selection is tested at utility value with the probability of selection of modes with rumors as follows:

$$
\begin{gathered}
\mathrm{P}(\mathrm{To})=\frac{\mathrm{e}-\mathrm{U}_{\mathrm{To}}}{\mathrm{e}-\mathrm{U}_{\mathrm{To}}+\mathrm{e}-\mathrm{U}_{\mathrm{Tu}}}=\frac{1}{1+\mathrm{e}-\left(\mathrm{U}_{\mathrm{Tu}}-\mathrm{U}_{\mathrm{To}}\right)} \\
\mathrm{P}(\mathrm{Tu})=1-\mathrm{P}(\mathrm{To})
\end{gathered}
$$

Where:

$\mathrm{P}(\mathrm{To})$ : Probability to use the online transportation mode 
$\mathrm{P}(\mathrm{Tu})$ : Probability to use the mass public transportation mode

e- ${ }_{\text {to,tu }}$ : Exponential Utility Mode

\section{Result and Analysis}

The emergence of online transport adds to the mode of public choice for travel. Currently, the use of online transportation is in demand by the community as a mode of accessibility better than public transportation. Based on the data that has been obtained following the percentage of choice of modes of transportation from the people of Semarang City in doing daily movement:

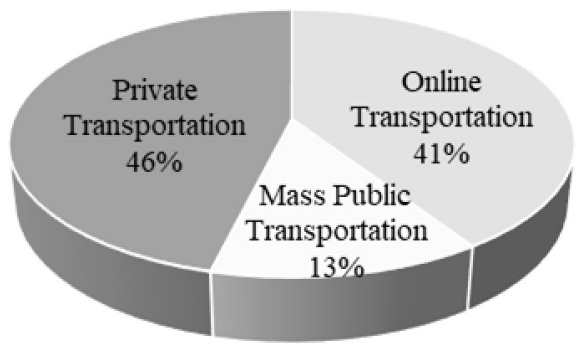

Fig. 1. Transportation Selection in Semarang City

Based on figure 1, the people of Semarang City prefer to use private vehicles rather than other modes of transportation. But the actual presence of online transport has become a dominant choice rather than a mass public mode of transport. The percentage of the selection of online transportation mode and private vehicles is only $5 \%$. It shows the use of the online mode of transportation and private vehicle dominantly selected travelers. The public is more dominant in choosing online transportation than mass public transportation is feared to reduce the presence and provision of mass public transportation.

The selection of online transportation mode was $5.4 \%$ as a male traveler, and $35.4 \%$ were female. It shows that women are more dominant in choosing to use online transport than other transportation. The age group that many prefer to use online transportation is at the age of teen of 17-25 years old and dominated by the 17-yearold population who still take education upper middle class 3. Age, of course, illustrates that the user of online transportation is widely used by students who are not yet has a driver's license (SIM) and has not owned a private vehicle because it has no income and each relies on his parents. At first, the teenagers, of course, use public transportation as a mode to leave and go home from school. But with the existence of this online transportation, the students switch to use it and rarely are still using public transportation.

The selection of online transportation mode was $5.4 \%$ as a male traveler, and $35.4 \%$ were female. It shows that women are more dominant in choosing to use online transport than other transportation. The age group that many prefer to use online transportation is at the age of teen of 17-25 years old and dominated by the 17-yearold population who still take education upper middle class 3. Age, of course, illustrates that the user of online transportation is widely used by students who are not yet has a driver's license (SIM) and has not owned a private vehicle because it has no income and each relies on his parents. At first, the teenagers, of course, use public transportation as a mode to leave and go home from school. But with the existence of this online transportation, the students switch to use it and rarely are still using public transportation.

The high selection of online and personal transportation modes, as many as $41 \%$ of online transportation voters and $46 \%$ who chose private vehicles certainly did not support the realization of lowcarbon cities in Semarang City. Therefore, to increase the probability of mass transportation mode selection, research on the utility factor which is the main reason for the online transportation is preferred from mass public transportation. The choice of this mode of transportation will be compared to the mode of mass public transportation in the city of Semarang. The selection is conducted between Trans Semarang as mass public transportation and Online Transportation. The following are the travel costs and travel time of each mode of transportation (table 1)

Table 1. Data of Transportation Use from Respondents Trips

\begin{tabular}{|c|c|c|c|c|c|c|}
\hline & Transportation & $\begin{array}{l}\text { RP } \\
39\end{array}$ & RP 7 & RP 1 & $\begin{array}{l}\text { RP } \\
86\end{array}$ & $\begin{array}{l}\mathrm{RP} \\
2\end{array}$ \\
\hline \multirow{2}{*}{$\mathrm{X} 1$} & $\begin{array}{l}\text { Online } \\
\text { Transportation }\end{array}$ & 6 & 27 & 3 & 12 & 10 \\
\hline & $\begin{array}{l}\text { Trans } \\
\text { Semarang }\end{array}$ & 3.5 & 3.5 & 3.5 & 3.5 & 1 \\
\hline \multirow{2}{*}{$\mathrm{X} 2$} & $\begin{array}{l}\text { Online } \\
\text { Transportation }\end{array}$ & 4 & 29 & 2 & 10 & 10 \\
\hline & $\begin{array}{l}\text { Trans } \\
\text { Semarang }\end{array}$ & 3.5 & 3.5 & 3.5 & 3.5 & 1 \\
\hline \multirow{2}{*}{ W1 } & $\begin{array}{l}\text { Online } \\
\text { Transportation }\end{array}$ & 10 & 20 & 7 & 12 & 10 \\
\hline & $\begin{array}{l}\text { Trans } \\
\text { Semarang }\end{array}$ & 45 & 40 & 15 & 30 & 15 \\
\hline \multirow{2}{*}{ W2 } & $\begin{array}{l}\text { Online } \\
\text { Transportation }\end{array}$ & 12 & 35 & 10 & 30 & 12 \\
\hline & $\begin{array}{l}\text { Trans } \\
\text { Semarang }\end{array}$ & 30 & 45 & 60 & 25 & 15 \\
\hline
\end{tabular}

Exp: $X 1=$ Travel Cost of Depart (in units of money); $X 2=$ Travel Cost of coming back home (in units of money); $W 1=$ Travel time of Depart (in minutes); $W 2=$ Travel Time of Come Back Home (in minutes);

\subsection{The utility of Travel Costs Value / Fares}

In the selection of online transportation mode and Trans Semarang will use binary logit difference model exemplified by Tamin in his book. In this research, the selection of modes is made between the mode of online transportation and Trans Semarang as mass public transportation. 
Table 2. Calculation of Logit Binary Models of Online Transport and Trans Semarang

\begin{tabular}{|c|c|c|c|c|}
\hline Models & $\mathrm{C}_{\mathrm{TO}}$ & $\mathrm{C}_{\mathrm{TS}}$ & $\mathrm{P}_{\mathrm{TO}}$ & $\mathrm{P}_{\mathrm{TS}}$ \\
\hline RP39 & 54 & 157 & 81 & 19 \\
\hline RP7 & 166 & 177 & 71 & 29 \\
\hline RP1 & 39 & 157 & 82 & 18 \\
\hline RP86 & 106 & 117 & 71 & 29 \\
\hline RP2 & 64 & 62 & 70 & 30 \\
\hline
\end{tabular}

Exp: $\quad C_{T O}=\mathrm{X} 1+\mathrm{X} 2+(2 . \mathrm{W} 1)+(2 . \mathrm{W} 2)=$ General of Online Transportation Fee; $C T S=X 1+X 2+(2 . W 1)+(2 . W 2)=$ General of Trans Semarang Fee; $P_{T O}=$ Probability of Online Transportation with Trans Semarang; PTS $=$ Probability of Trans Semarang with Online Transportation

In binary logit research in this Tamin's way, the general cost of travel mode can illustrate the selection of online transport modes with Trans Semarang as mass public transport. But the difference obtained in this calculation can't be known whether the value of time or the value of cost are the most influential. Besides, when looking at the cost of travel, mass public transport today has been cheaper than online transportation. But for travel time between modes of transportation online and public transportation can't be estimated because it will be different according to the conditions of travel that occurred at the time.

Therefore it will be recalculated using the same method but the cost factor and travel time will be separated. The calculation results will have the equal probability or not with the general cost calculation. The mode selection function can be obtained based on travel costs or fees only. This cost-utility function formula represents the number of costs incurred by the user on every trip away and work. It is because different expenses are incurred when using the mode of online transportation on the trip away and return trip to work. Here is the formula of the function of choosing the mode of online transportation and Trans Semarang as mass public transportation. Where:

$$
\text { UTO-TS }=0.826+(-0.057) \mathrm{X}_{1}+(0.003) \mathrm{X}_{2}
$$

$\mathrm{U} \quad=$ Mode Utility

TO = Online Transportation

TS = Trans Semarang

$\mathrm{X} 1=$ Travel Costs of depart by using of mode

$\mathrm{X} 2$ =Travel Cost of coming back home by using of mode

With the cost-utility formula obtained, here is the calculation in the selection of online transportation mode with Trans Semarang as public transport (Table 3).

Table 3. Calculation of Travel Cost Utility Functions Of Mode Choice on Online Transport and Trans Semarang

\begin{tabular}{|c|c|c|c|c|}
\hline \multirow{2}{*}{ Models } & \multirow{2}{*}{$\mathbf{X}_{\text {To }}$} & \multirow{2}{*}{$\mathbf{X}_{\text {TS }}$} & \multicolumn{2}{|c|}{ Probability } \\
\cline { 3 - 5 } & & & $\mathbf{P}_{\text {TO }}$ & $\mathbf{P}_{\text {TS }}$ \\
\hline RP39 & 10000 & 7000 & 46 & 54 \\
\hline RP7 & 56000 & 7000 & 22 & 78 \\
\hline RP1 & 5000 & 7000 & 51 & 49 \\
\hline RP86 & 22000 & 7000 & 39 & 61 \\
\hline RP2 & 20000 & 2000 & 38 & 62 \\
\hline
\end{tabular}

The results, utility function of the cost of online transportation mode and Trans Semarang show the probability value which tends to choose Trans Semarang. It indicates that the value of travel expenses using Trans Semarang is cheaper than using the mode of online transportation. But $40 \%$ of travelers still prefer to use online transportation, and only $13 \%$ of people choose public transportation. Previous research in motorcycles is preferred over public transport. Motorcycles or private vehicles are preferred because the value of costs incurred is cheaper than Trans Semarang as public transport modes [11].

Based on figure 2, travel costs from the mode of public transportation for Trans Semarang there are 74\% of users who cost less than Rp 5000. When compared with the online transport spend less than Rp 5000 only about $34 \%$ of users. It supports the cost of traveling in public transportation is cheaper than the mode of transportation online.

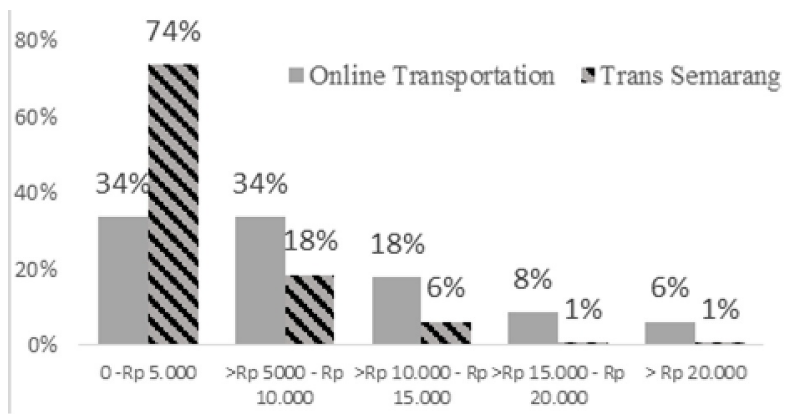

Fig.2. Composition Of Travel Cost with Online Transport and Mass Public Transportation

The cost value of this trip is not very influential on the selection of modes made by the user, this is evidenced by the cost of travel mass public transportation modes are cheaper, but the percentage of community mode selection is more dominant who choose the online transportation. It shows that there are still other influential factors. The next analysis will test the value factor of travel time, each mode of transportation against the selection of modes performed.

\subsection{The utility of Travel time value}

Here is the formula of the function of choosing the mode of online transportation with Trans Semarang as public transportation based on travel time:

$$
\mathrm{U}_{\mathrm{TO}-\mathrm{TS}}=0.845+(-0.066) \mathrm{W}_{1}+(-0.035) \mathrm{W}_{2}
$$

Where:

$\mathrm{W} 1$ = Travel time of depart by using mode

$\mathrm{W} 2$ = Travel time of coming back home by using of mode

Then performed a model test for the selection of modes based on the time utility function of each mode. Here is the calculation in the variety of online transportation and Trans Semarang as public transport (Table 4) 
Table 4. Calculation of Travel Time Utility Functions of Mode Choice on Online Transport and Trans Semarang

\begin{tabular}{|c|c|c|c|c|}
\hline \multirow{2}{*}{ Models } & \multirow{2}{*}{$\mathrm{W}_{\text {TO }}$} & \multirow{2}{*}{$\mathrm{W}_{\text {TS }}$} & \multicolumn{2}{|c|}{ Probability (\%) } \\
\cline { 4 - 5 } & & & $\mathrm{PTO}$ & $\mathrm{PTS}$ \\
\hline RP39 & 22 & 75 & 95 & 5 \\
\hline RP7 & 55 & 85 & 84 & 16 \\
\hline RP1 & 17 & 75 & 91 & 9 \\
\hline RP86 & 42 & 55 & 73 & 27 \\
\hline RP2 & 22 & 30 & 61 & 39 \\
\hline
\end{tabular}

Based on the results of the utility function of the time mode of online transportation and Trans Semarang as public transportation shows that the probability value tends to choose the mode of online transportation. It shows the travel time affects the choice of the mode by road users. It shows the value of time is critical in the movement of urban communities. It can be seen based on research data on users who have done before. Below is the travel time from the online transportation mode with mass public transportation (Figure 3).

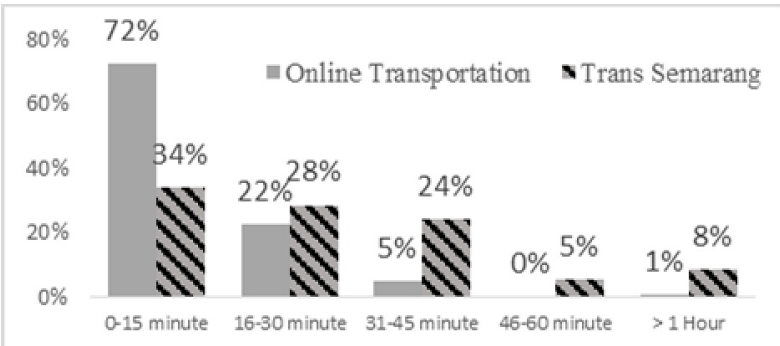

Fig.3. The composition of Travel Time with Online Transport and Mass Public Transportation

The value of this trip time turned out to affect the selection of modes made by the user; this is evidenced by the time of travel mass public transportation mode that is longer than online transportation so that more dominant people who choose online transportation. The value of the critical travel time in the selection of these modes can be corrected in every mass public transport mode to increase mass public transport users.

Improving the selection of mass public transport modes can now be done with improvements in travel time. Increasing use of mass public transportation will reduce private vehicle use and also the use of online transportation. So that efforts to create a low-carbon city can be realized by reducing $\mathrm{CO}^{2}$ emissions from vehicles. The existence of online transportation which is the development of the ride-sharing certainly not following the initial purpose of the ride sharing. So the principle of online transport today is more to para-transit or personal lease transport.

\section{Conclusion}

The research is to conduct the preference of online transportation mode compare to public transportation in Semarang City, based on the value of efficiency travel time factors. The result claim that people prefer using online transportation rather than public transportation.
The existence of online transportation as a car-sharing concept could not support the principal of a low-carbon city. Nowadays, the existence of online transportation will increase the number of private vehicles gradually. The evidence might be known as online transportation (compare with private transportation) is more dominant than mass public transportation. It may not support the concept of low-carbon cities due to the accumulation of motor vehicles emission. The highest emission discharge especially during the peak hours, when the number of vehicles has increased. It approved that online transportation is not in line with the concept of low carbon city.

\section{Recommendation}

Improving the selection of mass public transportation can be done with improvements regarding service. Especially in longer travel times compared with online transport. Provision of integrated microbus or have the same transit point with Trans Semarang can be a public transportation solution in Semarang City. Travelers do not have to walk to transit vehicles, and this will reduce the duration of travel from public transport. Faster duration will increase the use of mass public transport modes. The number of private vehicles will reduce the impact of reduced $\mathrm{CO} 2$ emissions Semarang city. To realize the city of Semarang as a low-carbon city.

\section{References}

1. A. R. Rakhmatulloh, I. Buchori, W. Pradoto, B. Riyanto, \& J.Winarendri, IOP Conf.: Earth \& Enviro. Scie., 123(1), 012033 (2018)

2. G. Meyer, Disrupting Mobility, (2017)

3. Y. Sebastian, Time Is More Valuable Than Money, (2013)

4. A. R Rakhmatulloh, I. Buchori, W. Pradoto, \& B. Riyanto, Plan. Malay., 16(1), 118-129 (2018)

5. M. M. M. Abdel-Aal, Alex. Engine. J., 56(4), 567578 (2016)

6. J. I. Toar, J. A. Timboeleng, \& T. K.Sendow, J. Sip. Sta., 3(1), 27-37 (2015)

7. J. Minx, K. Scott, G. Peters, \& J. Barrett, Scie. \& Techno., (2008).

8. S. Tan, J. Yang, J. Yan, C. Lee, H. Hashim, \& B. Chen, Appl. E., 185, 1919-1930 (2017)

9. A. Sugiyono, $M \& E, \mathbf{1 2}, 45-53$ (2015)

10. Akdon \& Riduwan. Rumus dan Data dalam Analisis Statistika. (2007)

11. Nasruddin \& A. R. Rakhmatulloh, Tek. PWK, 3(3), 406-417 (2014) 